\title{
A new paradigm of human rights in the context of the global threats development
}

\author{
Georgy Borisovich Romanovsky ${ }^{11}$, Olga Valentinovna Romanovskaya ${ }^{2}$, Vladislav \\ Georgievich Romanovsky ${ }^{1}$, Anastasia Andreevna Ryzhova ${ }^{2}$, and Olga Aleksandrovna \\ Ryzhova $^{1}$ \\ ${ }^{1}$ Penza State University, Department of Criminal Law, Institute of Law, Penza, Russia \\ ${ }^{2}$ Penza State University, Department of State and Legal Disciplines, Law Institute, Penza, Russia
}

\begin{abstract}
The purpose of the research is to formulate the general guidelines for the transformation of human rights as a result of global threats. The methodological framework was the methods of comparative legal research, which showed the general trends in the development of the human rights legislation under the influence of global threats. By the example of the responses of states to the terrorist attacks that occurred on September 11, 2001, it is shown how legislative innovations expanding the powers of law enforcement agencies and special services have led to the revision of the content of such basic human rights as the right to privacy and/or the right to personal inviolability. Highlighted is the concept of the "war on terror" (formulated by the United States President in 2001), which allows terrorists to be treated as representatives of a belligerent but without providing any international guarantees enshrined in the provisions of the international humanitarian law. The consequences of the introduction of biomedical technologies, that are aggressive towards humans, are presented, namely the creation of chimeric organisms that contribute to blurring the interspecific boundaries; creation of a genetically modified organism - human embryo; the development of an artificial uterus capable of bearing a human fetus practically from the time the male and female reproductive cells join. The results consist in the identified trends in the development of legal institutions, such as the formulation of new human rights often replacing or distorting the content of basic recognised human rights enshrined in the key international documents and constitutions of the countries of the world; bypassing the legal prohibitions established over the past decades by introducing relativism and assessing any situation from the point of view of the conditions for its occurrence. The novelty of the research lies in the authors' position and is formulated as follows: the modern system of human rights is facing a serious crisis. Failure to effectively respond to symbolic challenges and threats is one of the factors necessitating the need for monitoring many regulatory documents. But a significant reason for the backlash also lies in the fact that we are at the turn of an era when technology shows humanity the possibility of correcting the very nature of Homo sapiens.
\end{abstract}

Keywords: human rights, transformation, terrorism, biomedicine, threats, security.

\footnotetext{
${ }^{1}$ Corresponding author: vlad93@sura.ru
} 


\section{Introduction}

The coronavirus infection, like nothing else, has shown the fragility of the modern world, in which established values have been formed over several decades: open borders and globalisation; tolerance and rejection of national egoism; freedom and the right to privacy. Over the past year, their rapid revision could be observed: a ban on movement (even within a country), protectionism against national entrepreneurs, the extradition of foreigners and a ban on their entry, the introduction of quarantine restrictions and total control with digital technologies. All this raised serious concerns about the preservation of the renewed regime after the announcement of a possible return to the former social life. Henry Kissinger, in a policy article, proclaimed that the coronavirus pandemic will forever alter the world order [1].

Many states have also tested methods of exercising control over almost every step of a person, which aroused a certain interest among law enforcement agencies, who saw prospects in the fight against ordinary criminal acts and terrorism as an extreme form of anti-state activities. This led to statements by many international organisations, which emphasised the temporary nature of the restrictions and prohibitions introduced. The World Health Organisation has called on countries to abandon long-term compliance with quarantine and related measures after the danger of coronavirus infection has passed. At the same time, states should set a new agenda that takes into account the fragility of our planet and is related to not only returning to normal life but creating effective measures to prevent such situations [2].

The introduction of sanitary restrictions affected basic human rights (consider them by the example of Russian rules of conduct):

- the right to privacy - serious concerns are caused by the proliferation of face recognition systems based on NtechLab technologies provided by the Safe City programme;

- the right to freedom of movement - many countries are considering the introduction of so-called COVID passports, which leads to the resuscitation of the permissive procedure for movement, Russia is also involved in the discussion;

- the right to health protection - the fundamental right is transformed into an obligation, when a medical worker determines the scope of permissible behaviour, which gives rise to a special term in science, "bio-power" [3];

- the right to freedom of entrepreneurial activities - the announced lockdown stopped the possibility of doing business, without compensation for lost income and the possibility of earning profit in another way (only some benefits were provided for paying taxes and obtaining special loans).

This list can hardly be described as exhaustive. At the same time, the coronavirus infection has kindled the scientific discussions that are taking place around other global threats that appeared long before the pandemic and which have a significant impact on the human and civil rights and freedoms. The key ones can be designated as terrorism and biomedical technologies.

\section{Methods}

The methodological framework for the research includes the general, general-scientific and specific-scientific methods of cognition used by legal science in the object-subject sphere of cognition of the general theory of law. Analysis of global threats shows that they are universal in nature and affect all of humanity as a whole. This determines the relevance of the comparative legal research method. Initially, the influence of terrorist threats led to the search for new approaches to ensure that the society and state are safe. Most foreign 
researchers insist on changing the balance of values in matters of the relationship between human rights and freedoms, ensuring human independence from the state, and security. A new concept of "renewed consensus" is proposed [4, 5]. However, other approaches should also be highlighted, i.e. on the preservation of the equivalence of values $[6,7]$ and the complete subordination of human rights to the security requirements of the society and the state [8, 9]. Extreme judgments are also made about the complete collapse of the contemporary human rights, where the main argument is the impossibility of preventing the expanding criminal activity of modern terrorist organisations [10].

Such conclusions related to the assessment of counter-terrorism measures are extrapolated to the entire human rights system, which leads to a special approach to the assessment of the proposals put forward. Similar conclusions are formulated in the analysis of legal institutions undergoing change due to the development of biomedical technologies [11]. Experience has shown that rapidly developing microbiology determines the revision of many well-established legal principles, canons and rules of conduct. The proposed concept of ectogenesis - the origin of life outside the human body - is gaining an increasing number of supporters [12]. In the United States and Western European countries, the idea of extending constitutional personality to animals is gaining popularity [13]. The zoopolis concept has been developed [14]. These approaches provided the basis for formulating the main conclusions in the critical assessment of the new paradigm of human rights in today's context.

\section{$3 \quad$ Results and discussion}

The contemporary human rights system took shape after World War II. Even in the Charter of the United Nations, the dependence of various disasters (including wars) on the practice of non-recognition of fundamental human rights was recorded. This led to the adoption of the Universal Declaration of Human Rights on December 10, 1948, and then the International Covenants on Human Rights of 1966 (collectively, these documents are often referred to as the International Bill of Human Rights). Other documents adopted by the international community in the field of human rights, one way or another, build on the generally recognised catalogue, develop it, supplement it with interim measures and guarantees.

\section{$1.1 \quad$ Terrorism as a global threat}

The first challenge to the entire human rights system occurred on September 11, 2001, when large-scale terrorist attacks were carried out, the symbol of which was the attack on the twin towers of the World Trade Center in New York. Back then there were accusations of the imperfection of the created human rights protection system. For several decades, the common ideology was built on the basis of the main thesis: the consolidation and development of fundamental human rights provides the basis for the removal of tension and peace throughout the planet. It appeared that this could not save American citizens from a large-scale crime on the part of Al-Qaeda (banned in the Russian Federation and included in the international list of terrorist organisations).

A direct consequence of terrorism was the adoption of the Patriotic Act (already signed by the President of the United States on October 26, 2001), a long document, which was used to create conspiracy theories (due to the speed of discussion and approval at all stages of the legislative process). At the same time, the US President developed the concept of the "war against terror", which provided the basis for internal reforms, as well as justifying interference in the internal affairs of states hostile to the United States. 
It is necessary to note the versatility of the above concept, which makes it possible to give legitimacy to the majority of border (from the point of view of human rights) actions of security and intelligence agencies, law enforcement agencies and army units of the United States of America. From the point of view of international humanitarian law, war is a legal term embodied in the concept of an armed conflict that is either international or non-international. At the same time, there is no such thing as a war against terror, which allows terrorists to act according to the principle of the law of war (for example, to conduct air raids with bombing of various objects), or according to the principles of combating crime (terrorism is a criminal offence). In addition, a terrorist cannot be regarded as a prisoner of war who is thus not subject to the privileges of combatants (when falling into the power of the opposing belligerent). On the other hand, when analysing a conflict with the term "war", it is not necessary to treat terrorists as criminals (from the point of view of criminal law), whose guilt should be proven in the framework of criminal justice, while respecting the guarantees of the defendant's rights. As a belligerent, they can be killed without charge.

In their own country, the Patriot Act established a regime of extensive control over electronic communication. The automatic espionage system "Carnivore", as well as the subsequent similar "Omnivore" and "Etherpeek" programmes, was legalised.

The adoption of the Patriotic Act served to revise the anti-terrorism legislation in almost all countries of Western Europe. This was also stimulated by senior US officials, who perceived such adherence to a common policy as a commitment to allied relations. Italy adopted the Law of December 15, 2001 No. 438 "Urgent Measures to Combat International Terrorism", the UK in December 2001 - the Anti-terrorism, Crime and Security Act, 2001, Germany in January 2002 - the Law on Combating International Terrorism (Gesetz zur Bekämpfung des internationalen Terrorismus (TerrorBekämpfG)).

The past two decades have shown that the terrorist threat does not diminish its relevance, which leads to strengthening the anti-terrorist measures, expansion of the administrative powers of law enforcement agencies and differentiation of the criminal responsibility. In the United States, in 2015 (to replace the Patriot Act), the Freedom Act was adopted. A short poetic metaphor was intended to replace the real cumbersome title of the law, "To reform the authorities of the Federal Government to require the production of certain business records, conduct electronic surveillance, use pen registers and trap and trace devices, and use other forms of information gathering for foreign intelligence, counter-terrorism, and criminal purposes, and for other purposes". It is easy to see that there is no mention of freedom in it. Moreover, the adopted laws are transforming many institutions of criminal law. Thus, in some European countries (the Netherlands, Belgium, Great Britain), criminal liability has been introduced for visiting territories controlled by terrorist organisations. To prosecute, there is no obligation to prove the commission of any illegal act. The territorial presence is enough. The jurisdiction of states is expanding when the courts consider criminal cases concerning terrorists without the need to prove the crimes committed against the citizens of the country in which the charge is being brought. In a similar vector, legislation aimed at preventing terrorist activities is being developed. Administrative control (France, Great Britain) over persons suspected of involvement in terrorist activities is introduced. For the imposition of measures, there are enough reasonable suspicions that a citizen has a propensity for committing terrorist crimes, even if he/she did not commit any active actions. Back in 2004, the head of the International Commission of Jurists, N. Howen, summed up, "Counter-terrorism measures around the world are challenging all our basic concepts of the rule of law and human rights" [15]. 


\subsection{Biomedical technologies as a global threat}

Modern microbiology is developing at an accelerated pace, and its resulting inventions are becoming more aggressive towards human nature. The revision of the biological foundations of the life of Homo sapiens will undoubtedly lead to a revision of the humanitarian principles of social community. Here are just the key studies that underpin the transformation of many basic human rights:

- the creation of chimeric organisms contributes to not only blurring the interspecific boundaries (by the way, the spread of coronavirus occurred due to close interspecies contact) but also expansion of the constitutional legal personality [16]. For example, biologists are discussing the idea of creating a humanzee (human ape) [17]. In the United States, the Non-Human Rights Movement is active and insists on the extension of legal personality (including the political rights [18]) to humanoid apes, elephants and some other animals. Claims in defense of the rights of monkeys are currently being considered in the US courts. The Movement is supported by many representatives of the American legal science (in particular, Lawrence Tribe, professor of constitutional law at Harvard University). This issue is reflected in Russian science [19];

- the creation of a GMO human embryo leads to the practice of artificial editing of the nature of the unborn person. The Chinese researcher He Jiankui, who "corrected" the human genome in order to subsequently become immune to HIV infection, can be considered the pioneer. A similar experiment will find its supporters, you can initially protect yourself from some infectious diseases (also coronavirus). The expansion of such practices transforms the principle of equality of human and civil rights and freedoms. People, who have the best ability to learn foreign languages, physical endurance, mathematical thinking etc. from birth, can be born. The danger of a biological revolution is noted by many futurologists, such as F. Fukuyama [20], E. Toffler [21];

- the development of an artificial uterus capable of bearing a human fetus practically from the time the germ cells of a man and a woman join together. Successful experiments in the United States and Japan are already giving rise to fantasies about the origin of life outside the human body. At one time, the inventor of the term "ectogenesis" J. Holden predicted that by 2074 the birth of children naturally will be in only one third of all cases [22]. The original idea - to help mothers with constant threats of miscarriage in carrying are put on a back burner due to the initiatives of organisations of sexual minorities. Arguments about the ineffectiveness of natural reproduction, the emergence of the concept of "new motherhood" "without discontinuing work", the spread of reproductive opportunities to all social groups of the population are put forward [23].

The given facts and circumstances force modern jurisprudence to search for adequate legal regulation. A person, his/her rights and freedoms should not be lost in replicated legislative initiatives. Understanding this leads to the formulation of new human rights which runs into serious difficulties. Let us give a small example. Giving more technicality to the process of dying (when the appearance of life can be created with devices for a long time) led to the development of the right to death, which is actively supported in both Russian and foreign legal science. The absence of this right allows it to be derived from the content of the right to life (which is enshrined in modern international instruments and constitutions). However, the prevalence of this approach leads to its transfer to other rights. If the right to life includes the right to death, then the right to education can mean the right to ignorance, the right to health can mean the right to the lack of it. Such a logical chain can go on and on.

The second way out of this difficult situation is to bypass the legal prohibitions established over the past decades. Thus, R. Posner put forward the concept of "absolute formal prohibitions not strictly observed" [24], which is subject to serious criticism [25]. Its essence lies in the relativism of any fundamental values that change under the necessity of 
circumstances. Taking into account the historical situation, this interpretation has become typical for the courts of many countries of the world (including Russia). It is no coincidence that R. Posner, the author of the concept, is an acting American judge.

\section{Conclusion}

Thus, in any case, it should be agreed that the modern human rights system is undergoing a serious crisis. Failure to effectively respond to symbolic challenges and threats is one of the factors forcing monitoring of many regulatory documents. But a significant reason for the backlash lies in the fact that we are at the turn of an era when technology shows humanity the possibility of correcting the nature of Homo sapiens. The onset of the event (and it seems to happen pretty soon) will lead to the need for a new consensus. However, in this case, there are fears that the changes will have to be shaped by a new person already. Will he/she be able to accept a different reality (due to the human psyche, soul and body)? - this question still remains unanswered.

The research was carried out with the financial support of the Russian Foundation for Basic Research as part of the scientific project No. 20-011-00096

\section{References}

1. H. Kissinger, The Wall Street J. (2020). Accessed on: June 25, 2021. [Online]. Available:

https://www.wsj.com/articles/the-coronavirus-pandemic-will-forever-alter-the-world-or der-11585953005

2. WHO Manifesto for a healthy recovery from COVID-19. Accessed on: June 25, 2021. [Online]. Available:

https://www.who.int/news-room/feature-stories/detail/who-manifesto-for-a-healthy-rec overy-from-covid-19

3. P.D. Tishchenko, Bio-vlast v epokhu biotekhnologii [Bio-Power in the Age of Biotechnology] (IFRAN, Moscow, 2001)

4. D. McGhee, Building a Consensus on "National Security": Terrorism, Human Rights and "Core Values", in Security, Citizenship and Human Rights. Palgrave Politics of Identity and Citizenship Series (Palgrave Macmillan, London, 2010)

5. I. Prezelj, Intern. Stud. Interdisc. Polit. and Cult. J. 17(1), 145-158 (2015). https://doi.org/10.1515 / ipcj-2015-0010

6. I.D. Yagofarova, Rus. Justice, 9, 45-47 (2018)

7. O.A. Kolotkina, I.D. Yagofarova, Laws of Rus.: Exper., Analysis, Pract. 10, 94-97 (2017)

8. M. Ignatieff, Soc. Research 69(4), 1137-1158 (2002)

9. M.D. Kielsgard, California Western Intern. Law J., 36(2), 249-302 (2006)

10. R. Sanders, Rev. Intern. Stud. 44(1), 2-23 (2018). https://doi.org/10.1017/S0260210517000377

11. P.J. Esteves, J. Abrantes, H. Baldauf et al., Experim. \& Molec. Med. 50, 1-10 (2018). https://doi.org/10.1038/ s12276-018-0094-1

12. M.L. Solerte, J. Gynecol. Research and Obstetrics 6(3), 67-71 (2020)

13. R.C. Jones, Contemporary Justice Rev. 1-16 (2015). http://dx.doi.org/10.1080/10282580.2015.1093689 
14. S. Donaldson, W. Kymlicka, Zoopolis: A Political Theory of Animal Rights (Oxford UP, Oxford, 2011)

15. N. Howen, Speech, ICJ Secretary-General at the Biennial Conference 2004: Counter-terrorism and human rights, challenges and responses (2004). Accessed on: June 25, 2021. [Online]. Available: https://www.icj.org/wp-content/uploads/2012/04/icj_howen_biennial_speech_2004.pdf

16. G.B. Romanovsky, Newslet. Perm Univ. Legal Sci. 37, 260-271 (2017). http://dx.doi.org/10.17072 / 1995-4190-2017-37-260-271

17. W.-H. Li, M.A. Saunders, Nature, 437, 50-51 (2005)

18. D. Hooley, Res Publica: J. Soc. and Legal Philos. 24(4), 509-530 (2018). http://dx.doi.org/10.1007 / s11158-017-9374-1

19. D.B. Gorokhov, Yu.V. Gorokhova, Advokat, 11, 5-20 (2016)

20. F. Fukuyama, Nashe postchelovecheskoe budushchee: Posledstviya biotekhnologicheskoi revolyutsii [Our Posthuman Future: Consequences of the Biotechnological Revolution] (Progress, Moscow, 2004)

21. E. Toffler, Shok budushchego [Shock of the future] (AST, Moscow, 2002)

22. S. Chemaly, What Do Artificial Wombs Mean for Women? Accessed on: June 25, 2021. [Online]. Available: https://rewirenewsgroup.com/article/2012/02/23/what-do-artificial-wombs-mean-wom en/

23. M.R. Sargentini, Corriere della Sera, 18 luglio (2008)

24. R.A. Posner, Not a Suicide Pact: The Constitution in a Time of National Emergency (Inalienable Rights) (Oxford University Press, 2006)

25. R. Segev, Israel Law Rev. 42(2), 234-247 (2009). https://doi.org/10.1017/S0021223700000558 